\title{
T11 - Aprovechamiento de semillas de hule (Hevea brasiliensis L.) para alimentación de tilapia (Oreochromis niloticus $\mathbf{L}$.)
}

\author{
Gustavo A. Elías-Ogaldez*, Eduardo E. Chacón-Osorio \\ Centro de Estudios del Mar y Acuicultura, Universidad de San Carlos de Guatemala
}

*Autor al que se dirige la correspondencia: tavoelias@hotmail.com

\section{Resumen}

Se elaboró un concentrado artesanal para tilapia (Oreochromis niloticus L.) con la finalidad de contribuir al aprovechamiento de los subproductos del cultivo de hule (Hevea brasiliensis Müll. Arg) y de reducir los costos de producción de la tilapia. La investigación fue tipo aplicada y experimental, realizándose en la zona costera del Pacifico guatemalteco. Se concluyó que la harina de semilla de hule es un insumo apropiado para sustituir parcial o totalmente la harina de semilla de soya, en la formulación de concentrados artesanales para tilapia. Todos los tratamientos donde se utilizó harina de semilla de hule presentaron una mejor supervivencia y FCA frente al testigo. El tratamiento T3 presentó la mejor tasa de retorno marginal frente al testigo y los demás tratamientos. Por último, se recomienda continuar la investigación tomando en cuenta que la semilla de hule es deficiente en aminoácidos esenciales, los cuales se pueden adicionar para mejorar su rendimiento nutricional.

Palabras claves: Nutrición, concentrado artesanal, índices zootécnicos, Oreochromis niloticus, piscicultura

\begin{abstract}
$\mathrm{n}$ artisan concentrate for tilapia was made to contribute to the use of sub products of rubber (Hevea brasiliensis $\mathrm{A}_{\mathrm{L}}$.) and reduce production costs of tilapia (Oreochromis niloticus L.). The research was applied and experimental, performed in the coastal area of the Guatemalan Pacific. It was concluded that the rubber seeds meal is an appropriate input to partially or completely replace soybean meal in the formulation of craft concentrates tilapia. All treatments in which rubber seed meal were used showed a better survival and FCA against the control. The T3 treatment presented the best marginal return rate versus control and other treatments. Finally, it is recommended to continue the investigation taking into account that the rubber seeds is deficient in essential amino acids, which can be added to improve their nutritional performance.
\end{abstract}

Keywords: Nutrition, concentrated craft, zootechnical indexes, Oreochromis niloticus, pisciculture 